\title{
SUCCINYLCHOLINE DOSAGE BASED ON LEAN BODY MASS
}

\author{
NoRMan L. WULFSOHN", M.E.B., CH. (RAND), D.A. (ENGE.), F.F.A. (S.A.)
}

\section{INTRODUCTION}

TFE CLINECAL DOSE of succinylcholine is customarily based on body weight. The usual dose is calculated on the basis of $0.5 \mathrm{mg} / \mathrm{Kg}^{26.34}$ to $1 \mathrm{mg} / \mathrm{Kg}$. routine use of $50-100 \mathrm{mg}$. has been questioned, since smaller doses have been found to be quite adequate. ${ }^{0,17,22}$

Evans and Lehman ${ }^{13}$ assert that body weight can only be taken as a rough guide to dosage, for obviously one cannot compare the amount of relaxant required by a short obese woman to that required by a tall young athlete of equal weight. Distribution to the tissues must also be considered. ${ }^{10}$ Initially drugs are concentrated in highly perfused tissues, i.e. the lean body mass (LBM), rather than in vessel-poor tissues such as fat. Thus a drug not immediately inactivated or degraded would be distributed primarily into the LBM (or the total body water ${ }^{9}$ ), and only later would it enter sparsely perfused tissue such as fat.

Theoretically, therefore, it would be more appropriate to use lean body mass as a guide to dosage rather than the usually accepted total body weight. Using thiopentone as a model it has been shown that there was a clearer correlation between lean body mass and dose than between body weight and dose. ${ }^{44} \mathrm{~A}$ similar relationship has been shown to exist for halothane. ${ }^{45}$

This investigation was carried out to determine whether lean bady mass could be used as a guide for dosage of a drug which is rapidly hydrolysed enzymatically, such as succinylcholine.

\section{Method}

Sixty-six patients with normal respiratory and circulatory systems, normal liver function tests and free of neuromuscular disease were used in this study. Each patient was measured for height, weight and girth (umbilical position in expiration). The per cent fat and lean body mass were calculated from Weisberg's modification $^{40}$ of Gubner's formula. ${ }^{19,19}$

(1) Percent fat $=90-2$ (Height/ins. - Girth/ins.)

(2) $\mathrm{LBM}=(100-$ per cent fat $) \times$ weight $/ \mathrm{Kg}$.

Following induction with $4 \mathrm{mg}$ of thiopentone per $\mathrm{Kg}$ lean body mass, anaesthesia was maintained with $\mathbf{5 0}$ per cent nitrous oxide-oxygen supplemented for at least 5 minutes with one of halothane, methoxyflurane or meperidine, before the ulnar nerve was stimulated. The nerve was stimulated supramaximally, using sub-

"Associate Professor, Department of Anesthesiology, University of Texas Medical School at San Antonio, San Antonio, Texas.

Supported by NIH Grant $\$ 1$ S01 FR 05654-01.

Canad. Anaesth. Soc. J., vol. 19, no. 4, July 1972 
cutaneous needle electrodes, with a pulse of 0.2 msecs duration at a frequency of 15 per minute using a "Block-Aid Monitor" (Burroughs-Wellcome, Co.). Thumb movement was recorded on a Grass Model 7 Polygraph through a force displacement transducer (Grass FTO3C). After an adequate base line tracing had been obtained the calculated dose of succinylcholine was administered by injection into the distal end of an intravenous infusion tubing. The infusion was kept running at about 100 drops per minute.

Patients were sub-divided into three groups. In Group A ( 38 patients) the dosage of succinylcholine was calculated on the basis of $1 \mathrm{mg} / \mathrm{Kg}$ lean body mass. Twelve of these patients received a halothane-nitrous oxide-oxygen sequence, sixteen received methoxyflurane-nitrous oxide-oxygen and 10 received meperidinenitrous oxide-oxygen. In Group B (2l patients), succinylcholine was calculated at $0.8 \mathrm{mg} / \mathrm{Kg}$ lean body mass. All received a halothane-nitrous oxide-oxygen sequence. In Group $\mathrm{C}$ ( 7 patients), the dosage was reduced further to $0.6 \mathrm{mg} / \mathrm{Kg}$ lean body mass. Halothane-nitrous oxide-oxygen was used for maintenance in all cases. As soon as adequate relaxation had been produced, endotracheal intubation was performed. An assessment of the ease of intubation was made, especially with the lower dose of $0.6 \mathrm{mg} / \mathrm{Kg}$ lean body mass. A second dose of $0.8 \mathrm{mg} / \mathrm{Kg} \mathrm{LBM}$ was given after full recovery from the $0.6 \mathrm{mg} / \mathrm{Kg}$ LBM dose to permit comparison between these two dosage ranges.

Controlled ventilation was maintained manually at a rate of 12 to 14 per minute and the time of return of spontaneous respiration was recorded. In some few instances this was not possible due to other factors.

The percentage of neuromuscular blockade produced by succinylcholine was recorded, as was the time required for the muscle twitch to return to the original height ( 100 per cent recovery).

The dose administered, the duration of apnoea and the time required for the twitch to return to the original value were correlated with per cent fat, weight of fat in $\mathrm{Kg}$., lean body mass, total body weight and body surface area.

\section{Results}

\section{(a) Dosage}

Complete neuromuscular block was produced in all patients who received doses of succinylcholine based on $1 \mathrm{mg} / \mathrm{Kg}$ lean body mass and $0.8 \mathrm{mg} / \mathrm{Kg}$ lean body mass. However, when $0.6 \mathrm{mg} / \mathrm{Kg}$ lean body mass was administered an average block of only 96.7 per cent was produced (Table I).

Relaxation of oral structures and the larynx were quite adequate for endotracheal intubation at the $1.0 \mathrm{mg}$ and $0.8 \mathrm{mg} / \mathrm{Kg}$ lean body mass dose levels. However, in three of seven cases ( 43 per cent) intubation was performed with difficulty or was not performed at all because of inadequate relaxation following $0.6 \mathrm{mg} / \mathrm{Kg}$ lean body mass. In the remaining four cases ( 57 per cent), the relaxation was considered to be just adequate.

A dose calculated on the basis of lean body mass is better correlated to body surface area than to body weight (Table I). The mean doses given are shown in Table $\mathbf{I}$. 


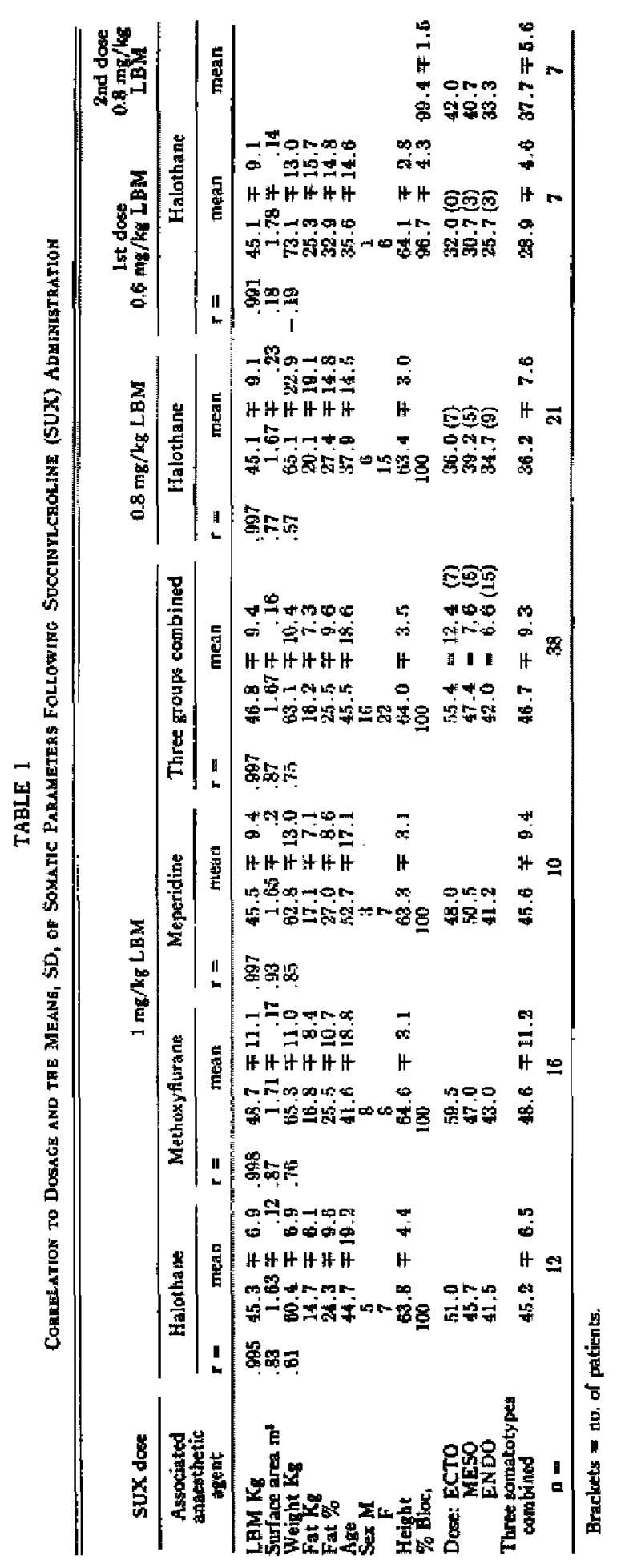




\section{(b) Apnoea}

Apnoea lasted longer after the larger dose, being 6.6 minutes following $1 \mathrm{mg} / \mathrm{Kg}$ lean body mass (average total dose $48.1 \mathrm{mg}$ ) and 5.9 minutes following $0.8 \mathrm{mg} / \mathrm{Kg}$ lean body mass (average total dose $36.2 \mathrm{mg}$ ) (Table II).

Duration of apnoea was shorter in endomorphs, (5.1 minutes with average dose of $41.7 \mathrm{mg}$ ) than in ectomorphs ( 7.8 minutes with average dose of $53.3 \mathrm{mg}$ ) following succinylcholine $1 \mathrm{mg} / \mathrm{Kg}$ lean body mass. At the dose level of $0.8 \mathrm{mg} / \mathrm{Kg}$ lean body mass apnoea lasted 4.9 minutes (average dose of $34.7 \mathrm{mg}$ ) and $6.6 \mathrm{~min}$ utes (average dose of $36.0 \mathrm{mg}$ ) respectively (Table II and VI).

Apnoca time following succinylcholine correlated poorly with body fat, but correlation was even less evident with dose, lean body mass or body weight (Table II), except in the halothane series following $1 \mathrm{mg} / \mathrm{Kg}$ of lean body mass.

\section{(c) Duration of Neuromuscular Blockade}

The time required for return of the twitch response to control values was similar at all dose levels ( 8.9 to 9.6 minutes at 28.9 to $46.8 \mathrm{mg}$ ).

Following a dose of $I \mathrm{mg} / \mathrm{Kg}$ lean body mass (average total dose $46.8 \mathrm{mg}$ ) recovery time was 9.6 minutes, after a dose of $0.8 \mathrm{mg} / \mathrm{Kg} \mathrm{LBM} \mathrm{(average} \mathrm{total} \mathrm{dose}$ $36.2 \mathrm{mg}$ ) it was 9.2 minutes, while 8.9 minutes was required for full return of the twitch response at the $0.6 \mathrm{mg} / \mathrm{Kg} \mathrm{LBM}$ dose (average $28.9 \mathrm{mg}$ ) (Table III).

Recovery time was shorter in endomorphs at 8.6 minutes (average dose of 41.8 $\mathrm{mg}, \mathrm{n}=12$ ) than in ectomorphs at 11.8 minutes (average dose of $56.0 \mathrm{mg}, \mathrm{n}=6$ ) after $1 \mathrm{mg} / \mathrm{Kg}$ lean body mass. This was also true at lower doses $(0.8 \mathrm{mg} / \mathrm{Kg}$ LBM) where endomorphs had a shorter recovery time of 7.7 minutes (average dose of $34.7 \mathrm{mg}$ ) than ectomorphs with 10.1 minutes (average dose of $36.0 \mathrm{mg}$ ) (Tables III and VI).

Recovery time was better correlated to per cent body fat at the higher dose levels of $1 \mathrm{mg} / \mathrm{Kg} \mathrm{LBM}$ and $0.8 \mathrm{mg} / \mathrm{Kg} \mathrm{LBM}$ (except in patients anaesthetised with halothane and using $1 \mathrm{mg} / \mathrm{Kg} \mathrm{LBM}$, while at the lower dosage of $0.6 \mathrm{mg} / \mathrm{Kg}$ LBM it correlated better to dose and lean body mass (Table III).

\section{Discussion}

\section{(a) Dosage}

Lean body mass was used as a basis for estimating dosage of succinylcholine in this study. Evans and Lehman ${ }^{19}$ pointed out that weight is only a rough guide and this is made evident by the marked variation in duration of action of succinylcholine ${ }^{2 a}$ when dosage is based on body weight.

Dosage calculated on the basis of lean body mass produced 100 per cent depression of muscle twitch in all cases where $1 \mathrm{mg} / \mathrm{Kg} \mathrm{LBM}$ or $0.8 \mathrm{mg} / \mathrm{Kg}$ were injected. These doses were adequate for unimpaired, easy endotracheal intubation. Katz and Ryan ${ }^{26}$ found that 90 to 100 per cent depression of twitch response always produced adequate relaxation in the presence of satisfactory light anaesthesia. In the present series the lower dose of $0.6 \mathrm{mg} / \mathrm{Kg}$ LBM was only adequate in 57 per cent of cases. This indicates that $0.8 \mathrm{mg} / \mathrm{Kg} \mathrm{LBM}$ is optimal, that the higher dose 


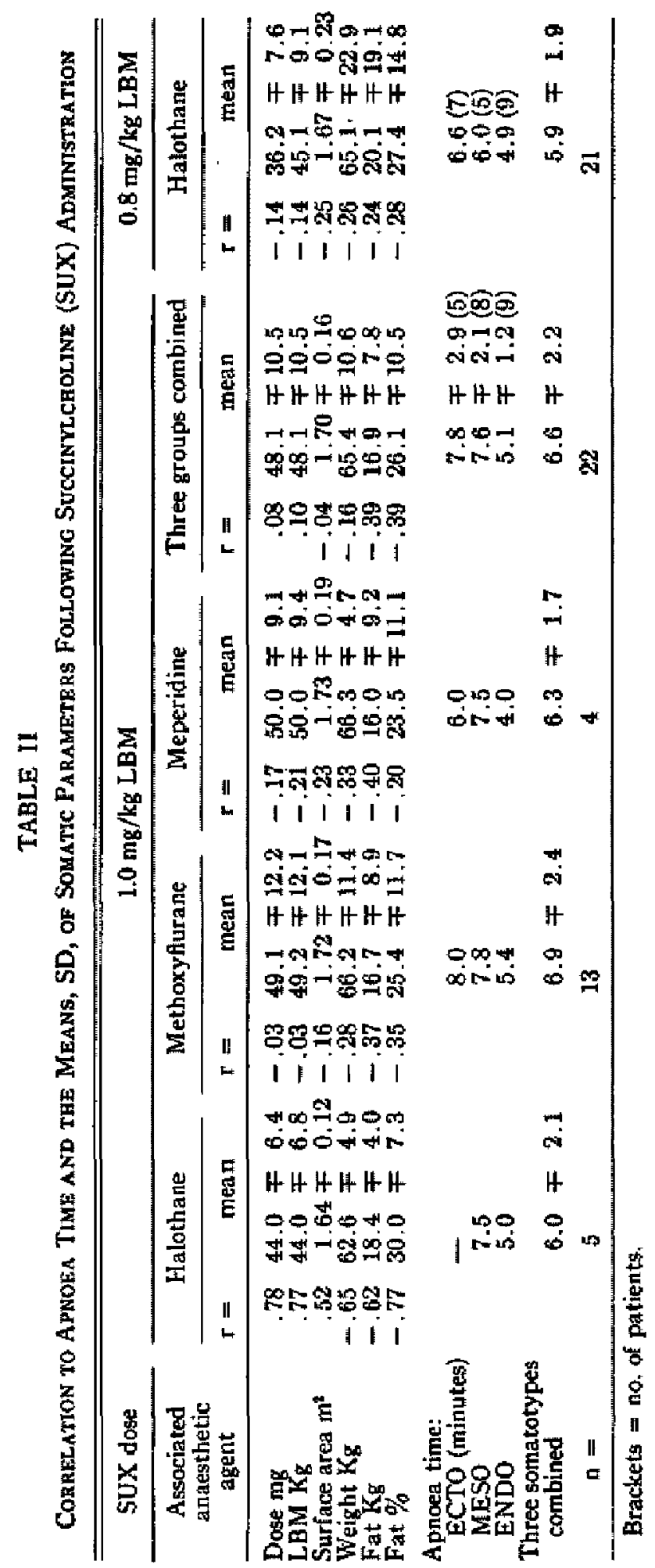




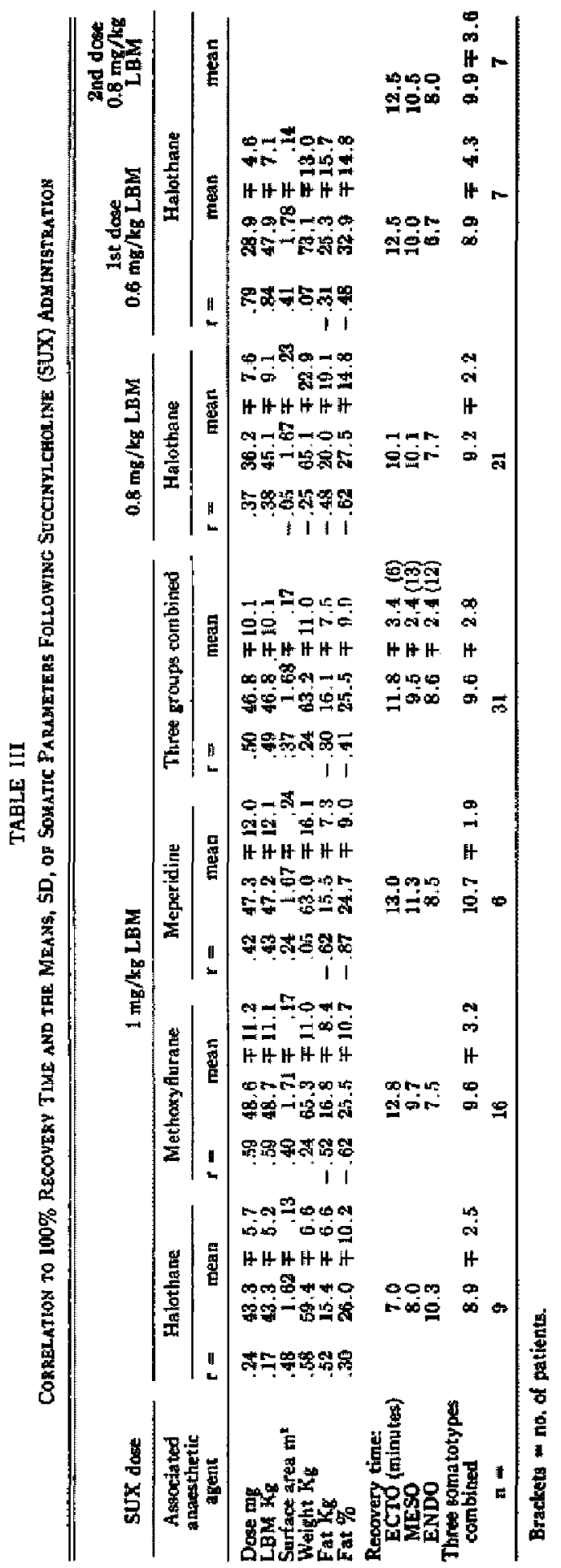


of $1 \mathrm{mg} / \mathrm{Kg} \mathrm{LBM}$ was excessive and that the lowest dose of $0.6 \mathrm{mg} / \mathrm{Kg} \mathrm{LBM}$ was inadequate.

Calculation of dose in the conventional manner based on total body weight, would have resulted in the administration of an excessive amount of drug. In nine obese patients (endomorphis) an average adequate dose of $34.7 \mathrm{mg}$ was given $(0.8 \mathrm{mg} / \mathrm{Kg} \mathrm{LBM})$. Calculated on the basis of body weight $(0.8 \mathrm{mg} / \mathrm{Kg} \mathrm{WT})$ an average dose of $61.5 \mathrm{mg}$ would have been administered. This is 77 per cent in excess of the dose that actually was required to produce the desired response. In five mesomorphs an average of $51.0 \mathrm{mg}$ would have been given instead of 39.2 $\mathrm{mg}$, which would have been an excess of 30 per cent. In seven ectomorphs an average dose of $36.0 \mathrm{mg}$ was found to be adequate. Based on body weight $41 \mathrm{mg}$ would have been administered, an excess of about 13.3 per cent. The latter small difference is not unexpected since in the ectomorph lean body mass approaches total body weight.

Calculation of the dose of succinylcholine at an even lower dose of $0.5 \mathrm{mg} / \mathrm{Kg}$ total body weight, ${ }^{26}$ would still have been in excess of the requirement in many patients, especially the obese. Relative overdosage thus produced is undesirable as it can cause prolonged apnoen even in the presence of normal plasma cholinesterase.

\section{(b) Apnoea}

Mendel and Rudney ${ }^{22}$ separated the cholinesterase enzymes into two groups, designated "true" cholinesterase and "pseudo" (or plasma) cholinesterase. Plasma cholinesterase is responsible for the enzymatic degradation of succinylcholine. However, there is a wide variation in normal serum cholinesterase activity with values from 620 to $1370 \mathrm{~m} \mathrm{U} / \mathrm{ml}$ (nanomoles of benzoylcholine hydrolysed per minute per $\mathrm{ml}$ of serum). ${ }^{28}$ Vickers $^{38}$ confirmed this wide variation (55 to 125 units $/ \mathrm{ml}$ ) as did Callaway et al. ${ }^{5}$ The latter found that sex, occupation and season had no effect upon esterase level, but that there is a variation from day to day in each individual. There is no particular correlation between age and cholinesterase levels. ${ }^{3, s}$ Whether cholinesterase levels are related to body somatotype is not known. However, a higher esterase level is said to occur in obesity. ${ }^{29}$ Paradoxically females, who commonly tend to have a greater percentage of fat, and consequently a lower lean body mass than males, ${ }^{40}$ tend to have lower esterase values than males, ${ }^{3}$ although Cathaway et al. ${ }^{5}$ did not find differences in cholinesterase levels linked to sex.

Succinylcholine is almost completely hydrolysed by plasma cholinesterase. The first step to succinylmonocholine and choline is rapid, but then succinylmonocholine is broken down more slowly to succinic acid and choline..4,41 The short duration of action of succinylcholine is attributed to this rapid hydrolysis by cholinesterase. It is not due to renal excretion, since only 2.8 per cent of the injected drug has been found unchanged in the urine in 30 minutes. ${ }^{14}$

Evans et $a l^{11}$ indicated that the duration of action was determined by the pseudocholinesterase level. Others have shown that there is some inverse relationship ${ }^{12,14}$ between duration of apnoea and cholinesterase level, although not a close one. 
TABLE IV

Duration of Apnoea Related to Dosage of Succinylcholine

\begin{tabular}{|c|c|c|c|}
\hline $\begin{array}{l}\text { Dose } \\
\text { succinylcholine chloride } \\
\text { mg }\end{array}$ & $\begin{array}{l}\text { Duration } \\
\text { of apnoea } \\
\text { (minutes) }\end{array}$ & $\begin{array}{l}\text { No. of } \\
\text { cases }\end{array}$ & Reference \\
\hline $\begin{array}{c}1,000 \\
1,000 \\
500 \\
250 \\
200 \\
60+(1 \mathrm{mg} / \mathrm{Kg} \mathrm{WT}) \\
\text { av. } 48.1(\mathrm{mg} / \mathrm{Kg} \mathrm{LBM}) \\
\mathrm{av} .36 .2(0.8 \mathrm{mg} / \mathrm{Kg} \mathrm{LBM}) \\
36^{*}(0.6 \mathrm{mg} / \mathrm{Kg} W \mathrm{WT}) \\
30^{*}(0.5 \mathrm{mg} / \mathrm{Kg} \text { WT }) \\
24^{*}(0.4 \mathrm{mg} / \mathrm{Kg} \text { WT })\end{array}$ & $\begin{array}{l}20 \\
19.5 \\
13.5 \\
9.6 \\
8.0 \\
8.4 \\
6.6 \\
5.7 \\
3.7 \\
3.1 \\
3.06\end{array}$ & $\begin{array}{c}8 \\
2.5 \\
9 \\
22 \\
21\end{array}$ & 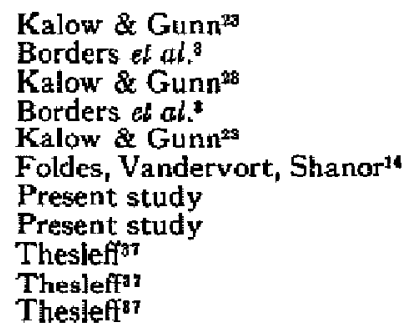 \\
\hline
\end{tabular}

*Calculated on $60 \mathrm{Kg}$ person using succinylcholine iodide.

tCalculated on $60 \mathrm{Kg}$ person.

Kalow and Gunn ${ }^{2 a}$ demonstrated that the duration of apnoea was correlated better to esterase level than to either age or weight. Borders et al. ${ }^{s}$ showed that even with large doses of succinylcholine the length of apnoea did not bear any relationship to cholinesterase activity, to the age of the patient nor to his general physical status. Prolonged apnoea has also occurred in patients despite a normal esterase level $1,12,80,43$

On the other hand some authors did find a relationship between duration of apnoea and dose, the duration increasing with an increase of dose ${ }^{\text {2a, } 83,37}$ When large doses of succinylcholine are given, the duration of apnoea is prolonged. Smaller doses have shorter apnoea times (Table III). In one study one thousand mg of succinylcholine caused an average apnoea time of 19.5 minutes, ${ }^{3}$ whilst 36.2 $\mathrm{mg}$ resulted in an average apnoea time of 5.9 minutes.

In the present study in both the $1 \mathrm{mg}$ and the $0.8 \mathrm{mg} / \mathrm{Kg}$ lean body mass groups, the duration of apnoea was related best to per cent fat; however, the correlation, which is an inverse one, was not good $(r=0.39$ or -0.28$)$. In the group that received halothane with the $1 \mathrm{mg} / \mathrm{Kg} \mathrm{LBM}$ dose of succinylcholine, the correlation between apnoea time and dose was $r=0.78$, with fat it was $r=0.77$ and with body weight it was $r=0.65$ (Table II).

Apnoea time was always shorter in the obese (endomorph) than in the thin (ectomorph) even though the dosage was much the same (Table VI).

Varying the anaesthetic agent used had little effect upon the apnoea time, irrespective of whether the agent was halothane, methoxyflurane or meperidine. Similarly Borders et al. ${ }^{3}$ found that other anaesthetic agents such as thiopentone and nitrous oxide, ether and cyclopropane do not alter cholinesterase activity, and Baraka ${ }^{4}$ demonstrated that halothane did not effect the action of succinylcholine.

The rarer occurrence of an excessively prolonged apnoea, which occurs in about 1 in 1200 to 1 in 3,000 patients ${ }^{1}$ can be due to a number of causes, such as:

(a) Absence of cholinesterase (silent genes, $\mathbf{E}^{\mathrm{s}}, \mathrm{E}^{\mathrm{s}}$ ) $^{2 \mathrm{~T}}$ occurring in 1 in 100,000 of population. 42

(b) Low serum cholinesterase, ${ }^{2,16,11}$ Cholinesterase is elaborated in the liver, 
TABLE V

Duration of Muscular Paratyșis to 90\% Recovery Related to Dosage of Sefccinyt.dicholine

\begin{tabular}{|c|c|c|c|c|}
\hline $\begin{array}{c}\text { Dose } \\
\text { mg }\end{array}$ & Dosage schedule & $\begin{array}{l}\text { No. of } \\
\text { patients }\end{array}$ & $\begin{array}{c}\text { Recovery time } \\
\text { to } 90 \% \\
\text { (minutes) }\end{array}$ & Reference \\
\hline $\begin{array}{l}28.9 \\
36.2 \\
46.8\end{array}$ & $\begin{array}{l}0.6 \mathrm{mg} / \mathrm{Kg} \text { LBM } \\
0.8 \mathrm{mg} / \mathrm{Kg} \text { LBM } \\
1.0 \mathrm{mg} / \mathrm{Kg} \text { LBM }\end{array}$ & $\begin{array}{r}7 \\
21 \\
31\end{array}$ & $\begin{array}{l}8.9+ \\
9.2 \dagger \\
9.6 \dagger\end{array}$ & $\begin{array}{c}\text { Present series } \\
" 1 \\
" 1\end{array}$ \\
\hline $\begin{array}{r}30^{*} \\
60^{*} \\
120^{*} \\
180^{*} \\
300^{*}\end{array}$ & $\begin{array}{l}0.5 \mathrm{mg} / \mathrm{Kg}_{\mathrm{gT}} \\
1.0 \mathrm{mg} / \mathbf{K}_{\mathrm{g}} W \mathrm{~T} \\
2.0 \mathrm{mg} / \mathbf{K}_{\mathrm{g}} W \mathrm{~T} \\
\mathbf{3 . 0 \mathrm { mg }} / \mathrm{K}_{\mathrm{g}} W \mathrm{~T} \\
5.0 \mathrm{mg} / \mathrm{Kg}_{\mathrm{g}}\end{array}$ & $\begin{array}{l}20 \\
10 \\
10 \\
10 \\
10\end{array}$ & $\begin{array}{l}10.1 \\
14.6 \\
18.1 \\
21.4 \\
40.2\end{array}$ & 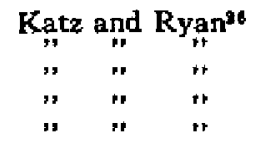 \\
\hline $\begin{array}{l}30^{*} \\
60^{*} \\
120^{*} \\
240^{*}\end{array}$ & $\begin{array}{l}0.5 \mathrm{mg} / \mathrm{Kg}_{\mathrm{g}} W \mathrm{WT} \\
1.0 \mathrm{mg} / \mathrm{Kg}_{\mathrm{g}} W \mathrm{WT} \\
2.0 \mathrm{mg} / \mathrm{Kg}_{\mathrm{g}} W \mathrm{WT} \\
4.0 \mathrm{mg} / \mathrm{Kg}_{\mathrm{g}} W \mathrm{~T}\end{array}$ & $\begin{array}{l}13 \\
13 \\
13 \\
13\end{array}$ & $\begin{array}{r}7.4 \\
12.1 \\
14.8 \\
19.6\end{array}$ & $\begin{array}{c}\text { Walts and Dillon } \\
" 1 " \\
" 1 " \\
" 1\end{array}$ \\
\hline
\end{tabular}

*Based on $60 \mathrm{~kg}$ WT.

$\uparrow$ Recovery to $100 \%$.

and parenchymatous liver damage can depress the enzyme level, as can malnutrition or debility. ${ }^{\text {s8 }}$ Only when levels fall below $20-25$ units $/ \mathrm{ml}$ does it cause prolonged apnoea (normal $55-125$ units $/ \mathrm{ml}$ ). ${ }^{38}$

(c) In a few cases a recessive gene is responsible for a qualitative change in the enzyme, causing reduced catalytic activity. ${ }^{30}$ This inherited defect is due to the presence of heterozygous or homozygous phenotypes determined by four allelic genes (usual $E^{u}$, atypical $E^{a}$, Silent $\mathbf{E}^{\mathbf{s}}$, and fluoride resistant $\mathbf{E}^{\mathfrak{l}}$ ), with ten possible genotype combinations. Besides the dibucaine and fluoride numbers, alcohol and chloride numbers have also been described, and more recently, formaldehyde has been shown to be an inhibitor of this enzyme. ${ }^{42}$ The frequency of the enzyme phenotypes in the population is low, $E^{t} E^{t}$ being 1 in 300,$000 ; E^{t} E^{s} 1$ in $200,000{ }^{31} E^{\mathrm{a}} \mathrm{E}^{\mathrm{a}} 3$ in 10,000 ; and $\mathrm{E}^{\mathrm{a}} \mathrm{E}^{\mathrm{x}} 5$ in 100,000 . $^{42}$

(d) Hypothermia ${ }^{28}$ may be associated with prolonged apnoea.

(e) Propanidid (Epontol ${ }^{(\mathbf{R})}$ ) inhibits cholinesterase.

(f) Relative overdose. ${ }^{\mathrm{s}}$

Although the fate of succinylcholine depends on normal serum cholinesterase activity, it is unlikely that differences in level of cholinesterase could fully explain 1,20 the marked variation in duration of action from single doses of succinylcholine, which may be a two- to four- or even five-fold variation. $3,15,26$

Variations in the factors of distribution in the body doubtless play a role in these differences of response. Blood flow, binding to plasma proteins and receptor proteins, ${ }^{2}$ distribution in total body water and body fat, plasma and extracellular water ${ }^{\theta}$ are such factors. Total body water reflects the size of the lean body mass ${ }^{40}$ and this varies from individual to individual.

Succinylcholine acts rapidly on the neuromuscular junction, causing muscle paralysis within one to one and a half minutes following injection. Hence the succinylcholine must leave the plasma rapidly to reach the neuromuscular junction. 
This is due to the special net of capillaries supplying the end-plate and the rapid diffusion over a minimal distance $(20 \mu)$ as the capillaties are in direct contact with the end-plate. ${ }^{20}$

Dal Santo ${ }^{8}$ has shown that after an intravenous injection of a trace amount of $\mathrm{C}^{14}$ labelled succinylcholine the bulk of the drug left the plasma rapidly for the extravascular space; that is the interstitial and intracellular compartments. He calculated that after 5 minutes 70 per cent of the dose had already entered the extravascular space and 10 per cent the urine, while only 20 per cent was still present in the plasma. About this time too the action of succinylcholine begins to subside. It is apparent that this is due to the drug slowly leaving the extravascular space to enter the urine."

Metabolic degradation is also partly responsible for the short-lived action of succinylcholine, since succinlymonocholine is found in the urine as early as 15 minutes after injection. ${ }^{\mathrm{s}}$

$\mathrm{Kalow}^{24}$ has calculated that normal cholinesterase would hydrolize $70 \mathrm{mg}$ of a $100 \mathrm{mg}$ dose of succinylcholine injected intravenously in one minute at $30^{\circ} \mathrm{C}$, and at $\mathrm{pH} 7.0$. This rate would be accelerated at $37^{\circ} \mathrm{C}$ and $\mathrm{pH} 7.38$. However, some drug escapes immediate breakdown by entering the tissues. ${ }^{\circ}$ Binding to plasma protein (albumin and globulin) is not important in the early phase of uptake, at the time of the peak of action. Dal Santo found that in the first 45 minutes the amount of binding of $\mathrm{C}^{14}$ succinyldicholine to plasma protein was negligible in dogs. Even though the duration of action is short much drug was still present in the extravascular compartment, which it leaves slowly for the urine. After 2 hours nearly 40 per cent of the dose was still present in the extravascular space, 60 per cent had now entered the urine, while only 1.5 per cent was still present in the plasma. ${ }^{\mathrm{s}}$

The same author reported that at 10 minutes a large amount ( 60 per cent) of the injected dose was still present in the extravascular space. ${ }^{8}$ Therefore, one might expect a smatler second dose would be needed to produce the same degree of action as the first. This is not the case. In this study a second dose $(0.8 \mathrm{mg} / \mathrm{Kg}$ lean body mass) given shortly after recovery from the first dose $(0.6 \mathrm{mg} / \mathrm{Kg}$ LBM) had essentially the same duration of action i.e. $9.9 \mathrm{~min}$ and $8.9 \mathrm{~min}$ for 100 per cent muscular recovery (See Table III). Katz et al., ${ }^{29}$ also found that a second dose has the same duration of action as the first.

\section{(c) Duration of muscular paralysis}

The duration of muscular paralysis is related amongst other things to cholinesterase level and to drug dosage. Dosage was well related to duration in cats ${ }^{30}$ and in man. ${ }^{\text {as }}$

After $30 \mathrm{mg}$ of succinylcholine, 90 per cent recovery took 10.1 minutes and after $300 \mathrm{mg}$ it took 40.2 minutes (Table V). In the present series after $1.0 \mathrm{mg} / \mathrm{Kg} \mathrm{LBM}$ time to complete recovery was longer than after the smaller dose of $0.8 \mathrm{mg} / \mathrm{Kg}$ LBM, which in its turn was longer than after $0.6 \mathrm{mg} / \mathrm{Kg}$ LBM. However, the difference in time was small. The recovery time was not influenced by the type of anaesthetic drug administered in association with the succinylcholine.

In obese individuals the recovery time is shorter. Obese patients of similar lean 
body mass to a thin group, and consequently receiving similar doses, took less time to full recovery.

TABLE VI

The Mean Values Showing the Difference im Apnoen Time and 100\% Recovery Time From Muscular Paralysis in a Group of Patjents With Fat and Thin Subjects Receiving Nearty Similar Doses of Succinylcholine With Halothane. Fat People Recover Sooner

\begin{tabular}{lccccccc}
\hline Somatotype & $\mathrm{n}=$ & $\begin{array}{c}\% \\
\text { Fat }\end{array}$ & $\begin{array}{c}\mathrm{LBM} \\
\mathrm{Kg}\end{array}$ & $\begin{array}{c}\mathrm{SUX} \text { Dose mg } \\
0.8 \mathrm{mg} / \mathrm{K}_{\mathrm{gBM}} \mathrm{LB}\end{array}$ & $\begin{array}{c}\text { Apnoea } \\
\text { time } \\
\text { (minutes) }\end{array}$ & $\begin{array}{c}100 \% \\
\text { Recovery time } \\
\text { (minutes) }\end{array}$ & $\begin{array}{c}\text { Weight } \\
\mathrm{Kg}\end{array}$ \\
\hline Ectomorph & 7 & 13 & 44.4 & 36.0 & 6.6 & 10.1 & 51.0 \\
\hline Endomorph & 9 & 41 & 43.3 & 34.7 & 4.9 & 7.7 & 76.9 \\
\hline
\end{tabular}

In the present series in Group B $(0.8 \mathrm{mg} / \mathrm{Kg}$ LBM) obese patients required 7.7 minutes for complete muscle recovery, whereas thin patients recovered in 10.1 minutes (Table VI).

The recovery time is also better related to per cent fat $(r=-0.62)$ than to dose or lean body mass $(r=0.38$ ) at the recommended dosage of $0.8 \mathrm{mg} / \mathrm{Kg} \mathrm{LBM}$. However the relationship to lean body mass is better than the relationship to body weight (Table II).

Lee and Atkinson ${ }^{29}$ state that high cholinesterase levels occur in obesity and this could possibly account for the more rapid recovery from succinylcholine in fat people. Furthermore, adipose tissue in experimental animals contains more cholinesterase than do blood, liver or kidney. ${ }^{35}$

\section{SUMMARY}

Although the dose of succinylcholine is customarily based on body weight this can be taken only as a rough guide. In the early phase after intravenous injection succinylcholine is partly removed by breakdown through the action of cholinesterase and in part by redistribution into the lean body mass. Sixty-six patients were given doses of succinylcholine based on lean body mass. $0.8 \mathrm{mg} / \mathrm{Kg} \mathrm{LBM}$ was found to be quite adequate for complete muscle relaxation, permitting easy and atraumatic endotracheal intubation in all cases. Lean body mass was a better guide to dosage than body weight.

Length of apnoea and duration of muscular paralysis were dose related; the bigger the dose the longer the response. However at $0.8 \mathrm{mg} / \mathrm{Kg} \mathrm{LBM}$ they were better correlated with fat than with dose.

Obese people have a relatively shorter recovery time from apnoea and muscular paralysis.

\section{RÉSTUMÉ}

A poids égal, une personne maigre et une personne grasse ne demandent pas la même dose de succinylcholine; la personne grasse en demande moins. Si toutefois la dose est calculée d'après le poids du corps, elle est exagérée, surtout pour les personnes grasses. Mais si elle est calculée sur la base de la masse corporelle maigre ( $0.8 \mathrm{mg} / \mathrm{kg} \mathrm{MCM}$ ), on évite la dose excessive. Cette dose MCM est toujours suffi- 
sante pour produire 100 pour cent d'arrêt des contractions musculaires et pour amener des conditions idéales pour une intubation facile.

La durée d'apnée (moyenne de 5.9 minutes) après la succinylcholine est plus longue à la suite de grosses doses, mais moins longue chez les obèses. De même, le temps requis pour le retour à 100 pour cent des contractions musculaires (moyenne 9.2 minutes) est plus long à la suite de grosses doses, et moins long chez les obèses.

\section{ACKNOWLEDGMENT}

With thanks for help with the statistics to Prof. R.G. Domey and J. Winstel, M.S., Biomedical Statistics, Dept. of Bio-engineering, University of Texas Medical School, San Antonio.

\section{REFERENCES}

1. Angent, D., Dnnvick, O., \& Hobeicer, F. Prolonged apnoea after suxamethonium in man. Brit. J. Anaesth., $27: 24$ (1955).

2. Bounne, J., CoLlien, $\mathrm{H}_{r}$ \& Somens, G. Succinylcholine (sticcinoylchotine) muscle relaxant of short duration. Laneet 262: 1225 (1952).

3. Bonders, R.W., StEPHEN, C.R., Nown.l, W.K. \& MARTn, R. The interrelationship of cholinesterases during anesthesia. Anesthesiol, I6: 401. (1955).

4. Baraka, A. Effect of halothane on tubocurarine and suxamethonium block in man. Brit. J. Anaesth. 40; 602 (1988).

5. Callaway, S., Davies, D., \& Rutland, J. Blood cholinesterase levels and range of personal variation in a healthy adult population. Brit. Med. J., ii, 812 (1951).

6. Chlvert, J., Lemmann, H., Silk, E., \& Slack, W. Prolonged apnoea after suxamethonium. Lancet, Aug. 21, 354 (1954).

7. Cohen, P., Reynolds, R, \& Naidu, J. A simple test for psendo-cholinesterase. Anesthesiol. $32,3,281$ ( 1970$)$.

8. Dal Santo, G. Kinetics of distribution of radioactive labeled muscle relaxants III Invertigations with 14 C-succinyldicholine and 14 C-succinylmonocholine during controlled conditions. Anesthesiol. 29, 3, 435 (1968).

9. Domnicre, A., St. Schminger, \& Kremer, I. Suxamethonium and serum cholinesterase. Brit. J. Anaesth, 40: 834 (1968).

10. Egr., E.1. Respiratory and circulatory factors in uptake and distribution of volatile anaesthetic agents. Brit. J. Anaes. $36: 155$ ( 1964 ).

11. Evans, F., Gray, P., Lemmann, H., \& Silx, E. Sensitivity to succinylcholine in relation to serum cholinesterase. Lancet, June 21, 1229 (1952).

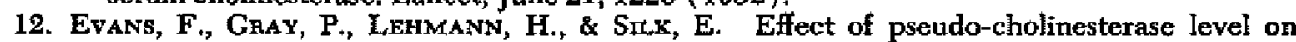
actions of succinylcholine in man. Brit. Med. J. i, 136 (1953).

13. Evans, F. L Lemmann, H. Prolonged apnoea after suxamethonium. Lancet, Sept. 18, 601 ( 1954$)$.

14. Foldes, F.F., Vandenvont, R.S., \& Shanon, S.P. The fate of succinylcholine in man. Anesthesiol. 16, 1, 11-21 (1955).

15. Fol.Des, F.F. \& NorTon, $\$$. The urinary excretion of succinyldicholine and succnylmonocholine in man. Brit. J. Pharmacol. 9: 385 (1954).

16. Forbat, A., Lehmans, $H_{\text {, }}$ \& Smx, E. Prolonged appoea following injection of succinyldicholine. Lancet, Nov. 21, 1067 (1953).

17. Frasks, E.H. Prolonged apnoea following suxamethonium. Lancet, Dee. 26, 1210 (1953).

18. Gubnen, R.S. Fatness, fat and coronary heart disease. Nutr. Rev, 15; 353 (1957).

19. Cubneq, F.S. Simple anthropometric indices of body fatness and heart size. Clin. Res. 9: 15 (1961).

20. Hall, L., Lemmank, H., SILK, E. Response in dogs to relaxants derived from succinic acid and choline. Brit. Med. J., $1: 134$ (1953).

21. HART, S.M. \& MITCHELL, J.V. Suxamethonium in the absence of psendocholinesterase. Brit. J Anaesth., 34: 207 (1962).

22. Hooces, R. Frolonged apzeea following succinyldicholine. Lancet, Dec. 5, 1358 (1953). 
23. Kanow, W. G GN, D.R. The relation between dose of succinylcholine and duration of apnoea in man. J. Pharm, \& Exper. Therap., 120: 203 (1957).

24. KakOW, $W$, The distribution, destnetion and elimination of muscle relaxants. Anesthesiol. $20,2,505$ (1959).

25. Ka1,OW, W. Relaxants in : Uptake and Distribution of Anesthetic Agents, Ed. Papper, E.M. and Kitz, R.J. New York; McGraw-Hill Co. pp. 302-309 (1963).

26. Katz, R. \& ByAN, J. The neuromuscular effects of suxamethonium. Brit. J. Anaesth., 4I: 381 (1969).

27. Katz, R., Nonman, J, Seed, R, Conzad, L. A comparison of the effects of suxamethonium and tubocurarine in patients in London and New York. Brit. I. Anaesth., $41: 1041$ (1989).

28. Kivc. J. \& Dixon, R. A further factor contributing to inherited suxamethonium sensitivity. Brit. J. Anaesth., $41 ; 1023$ (1969).

29. LEE, J.A.\& AtKonson, R.S. A Synopsis of Anesthesia, p. 468. Baltimore: The Williams and Wilkins Co. (1964).

30. LemmanN, H. \& Ryan, F, The familial incidence of low psendocholinesterase level. Lancet, 2; 124 (1956).

31. LefmaNN, H. \& Lmptix. Humaz cholinesterase (pseudocholinesterase); genetic variants and their recognition. Brit. J. Anmesth. $41: 235$ ( 1969 ).

32. MENDEL, B. \& Rudney, H. Studies on Cholinesterase I Cholinesterase and pseudo-cholinesterase. Biochem. J. 37, 1, 59-63 (1943).

33. MAYrirofea, O.K. Self experiments with succinylcholine chloride. Brit. Med. J. i, 1334 (1952).

34. Ruchares, H. \& Youncman, H. The ultra-short acting relaxants. Brit. Med, J, i, 1334 (1952).

35. Salvador, R.A. \& Kuntzman, R. Cholinesterase of adipose tissue. J. Pharm. \& Expex. Therap, 150, 1,85 (1965).

36. THustlEF, S. The pharmecological properties of succinylcholine iodide. Acta. Physiol. Scand, 26: 103 (1952a).

37. TheslefF, $\mathrm{S}$. An investigation of muscle relpxing action of succinyleholine iodide in man. Acta. Physiol. Scand. 25: 348 (1952b).

38. Vickens, M.D. The cholinesterases and their significance to the anaesthetist using muscle relaxants. Brit. J. Anaesth. 35: 528 (1963).

39. Walts, L. \& Dnfon, J.B. Clinical studies on succinyleholine chloride. Anesthesiol. 28, 2, 372 (1967).

40. Weiseneng, H.F. Water, Electroylte and Acid-Base Balance, and ed. Baltimore: Williams \& Wikins (1962).

41. WhrtTaker, M. \& Wyesusara, $\mathbf{S}$. Hydrolysis of succinyldicholine by cholinestarase. Biochem, J. 52: 475-9 (1952).

42. Whittaker, M. Genetic aspects of succinyleholine sensitivity. Anesthesiol. 32, 2, I43 (1970).

43. Worfrens, P. Sensitivity to succinylcholine chloride. Brit. Med. J. 2: 77.8 (1952).

44, Wulfsorn, N.L. \& Joshi, C.W. Thiopental dosage based on lean body mass. Brit. J. Anaesth. 4I: 516 (1969).

45. Wurforn, N.L. Halothane dosage based on lean body mass. Brit. J. Anaesth. 41: 522 (1969). 